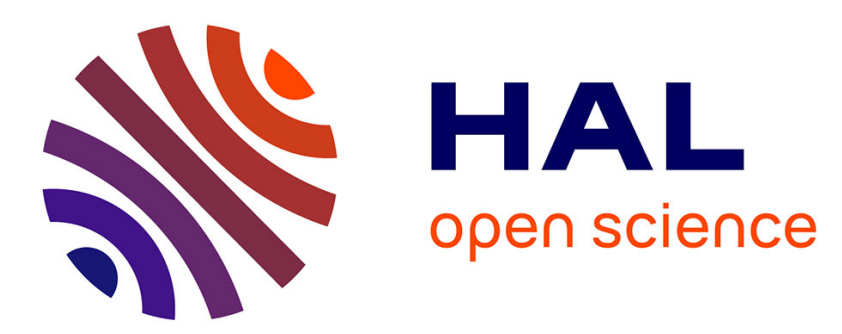

\title{
Molecular Pathology of the FSH receptor: new insights into FSH physiology
}

G. Meduri, A. Bachelot, M.P. Cocca, C. Vasseur, P. Rodien, F. Kuttenn, P. Touraine, M. Misrahi

\section{- To cite this version:}

G. Meduri, A. Bachelot, M.P. Cocca, C. Vasseur, P. Rodien, et al.. Molecular Pathology of the FSH receptor: new insights into FSH physiology. Molecular and Cellular Endocrinology, 2008, 282 (1-2), pp.130. 10.1016/j.mce.2007.11.027 . hal-00531970

\section{HAL Id: hal-00531970 https://hal.science/hal-00531970}

Submitted on 4 Nov 2010

HAL is a multi-disciplinary open access archive for the deposit and dissemination of scientific research documents, whether they are published or not. The documents may come from teaching and research institutions in France or abroad, or from public or private research centers.
L'archive ouverte pluridisciplinaire HAL, est destinée au dépôt et à la diffusion de documents scientifiques de niveau recherche, publiés ou non, émanant des établissements d'enseignement et de recherche français ou étrangers, des laboratoires publics ou privés. 


\section{Accepted Manuscript}

Title: Molecular Pathology of the FSH receptor: new insights into FSH physiology

Authors: G. Meduri, A. Bachelot, M.P. Cocca, C. Vasseur, P. Rodien, F. Kuttenn, P. Touraine, M. Misrahi

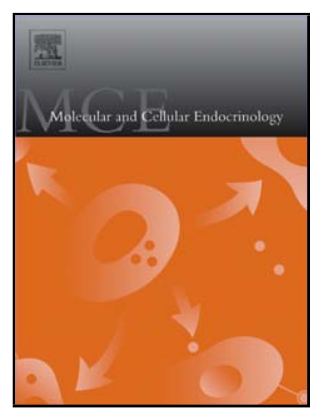

PII:

S0303-7207(07)00421-2

DOI: doi:10.1016/j.mce.2007.11.027

Reference: MCE 6748

To appear in: $\quad$ Molecular and Cellular Endocrinology

Please cite this article as: Meduri, G., Bachelot, A., Cocca, M.P., Vasseur, C., Rodien, P., Kuttenn, F., Touraine, P., Misrahi, M., Molecular Pathology of the FSH receptor: new insights into FSH physiology, Molecular and Cellular Endocrinology (2007), doi:10.1016/j.mce.2007.11.027

This is a PDF file of an unedited manuscript that has been accepted for publication. As a service to our customers we are providing this early version of the manuscript. The manuscript will undergo copyediting, typesetting, and review of the resulting proof before it is published in its final form. Please note that during the production process errors may be discovered which could affect the content, and all legal disclaimers that apply to the journal pertain. 


\section{Molecular Pathology of the FSH receptor: new}

\section{insights into FSH physiology.}

G Meduri ${ }^{1,2}$, A Bachelot ${ }^{3}$, MP Cocca ${ }^{4}$, C. Vasseur ${ }^{5}$, P Rodien ${ }^{6,7}$, F Kuttenn ${ }^{3}$, P Touraine $^{3}$ and M Misrahi ${ }^{1,8,9}$.

${ }^{1}$ Laboratory of Molecular Genetics, Pharmacology and Hormonology, AP-HP and ${ }^{2}$ IFR Bicêtre, Medical Faculty, Bicêtre Hospital, University Paris Sud 11, Le Kremlin Bicêtre, F-94275 France ${ }^{3}$ Department of Endocrinology and Reproductive Medicine, Pitié Salpêtrière, Hospital, 75651 Paris Cedex 13. ${ }^{4}$ Department of Pathology, University of Bari, Piazzale G. Cesare, Bari 70100, Italy. ${ }^{5}$ Service of Obstetrics Gynecology CHU of Angers, Angers, France. ${ }^{6}$ INSERM EMI Unité 0018. ${ }^{7}$ Endocrinology Service CHU of Angers, 49033, Angers, France. ${ }^{8}$ INSERM U 854, Medical Faculty, Bicêtre Hospital, Le Kremlin Bicêtre, F-94275 ${ }^{9}$ Corresponding author.

\section{Abstract}

Manipulations of mouse genome have helped to elucidate gonadotropin function but important differences subsist between rodent and human reproduction. Studies of patients with mutations of gonadotrophins or gonadotrophin receptors genes allow understanding their physiological effects in humans. The correlation of the clinical phenotypes of patients with in vitro studies of the mutated receptor residual function and histological and immunohistological studies of the ovarian biopsies permits to understand which stages of follicular development are under FSH control. Total FSHR inactivation causes infertility with an early block of follicular maturation remarkably associated with abundant small follicles as in prepubertal ovaries and 
demonstrates the absolute requirement of $\mathrm{FSH}$ for follicular development starting from the primary stage. Partial FSHR inactivation, characterized by normal sized ovaries, can sustain follicular development up to the early antral stages but incremental levels of FSH stimulation seem to be required for antral follicular growth before selection. These findings contrast with the traditional view of an initial gonadotrophin-independent follicular growth prior to the preantral-early antral stages. The presence of numerous reserve follicles in the ovaries of these patients may permit a future treatment of their infertility. The study of reduced $\mathrm{FSH} \beta$ or FSHR activity in genetically modified male mice models and in men suggests a minor impact of the FSHR on masculine fertility. Further studies on patients with a demonstrated total FSH $\beta$ or FSHR inactivation are required to elucidate reported differences in spermatogenesis impairment. Finally, the studies of mutations of gonadotrophins and their receptors demonstrate differences in gonadotrophin function between genetically modified rodents and humans which suggest prudence in extrapolating observations in rodents to human reproduction. Ovarian hyperstimulation syndrome (OHSS) can infrequently arise spontaneously during pregnancy, but most often it is an iatrogenic complication of ovarian stimulation treatments with ovulation drugs for in vitro fertilization. The first genetic cause of familial recurrent spontaneous OHSS was identified as a broadening specificity of the FSHR for hCG due to naturally occurring heterozygous constitutive mutations located unexpectedly in the transmembrane domain of the FSHR. Broadening specificity of a G protein coupled receptor is extremely rare. These observations led to the identification of the etiology of this previously unexplained syndrome and permitted to conceive novel models of FSHR activation. Susceptibility to iatrogenic OHSS or its clinical severity may be associated with FSHR polymorphisms with 
slightly different activities in vivo as suggested by several studies. The study of larger cohorts is needed to evaluate the clinical impact of these observations in the management of patients undergoing IVF protocols.

\section{Introduction}

$\mathrm{FSH}$ and $\mathrm{LH}$ receptors play a key role in reproduction. The $\mathrm{FSH}$ receptor (FSHR) is expressed in the granulosa cells of the ovary and in the Sertoli cells of the testes. Its activation promotes folliculogenesis and supports spermatogenesis in cooperation with the activated LH receptor (Baird, 2006). However, the precise steps of folliculogenesis and spermatogenesis which are under FSH control in humans are unclear.

Human gene mutations offer rare occasions to study human physiology. Manipulations of mouse genome have greatly helped in the understanding the function of several genes involved in reproduction (Abel et al., 2000; Burns et al., 2001; Kumar, 2005). However their observations cannot be applied directly to humans because of the differences between rodent and human reproduction. The study of mutations and polymorphisms of genes regulating female and male reproductive functions (Huhtaniemi, 2002; Themmen \& Huhtaniemi, 2000) (Themmen, 2005) has helped clarify many mechanisms of gonadic function and fertility in humans. In particular, the data obtained from patients with genetically altered gonadotrophins or gonadotrophin receptors have elucidated the molecular pathology of reproductive syndromes of hitherto unexplained etiology and of the respective physiological effects of $\mathrm{LH}$ and $\mathrm{FSH}$ on target organs.

The glycoprotein hormones receptors are a highly conserved subgroup of $\mathrm{G}$ protein coupled receptors (GPCR) displaying seven hydrophobic transmembrane spanning 
domains and characterized by a large $\mathrm{N}$ terminal extracellular domain. This $\mathrm{N}$ terminal domain is responsible for the specific recognition and binding of the receptor cognate ligands. The transmembrane domain has a rhodopsin-like structure (Palczewski et al., 2000). The ligand bound ectodomain of the FSH receptor has been recently crystallized (Fan \& Hendrickson, 2005a). This ectodomain is composed of leucine-rich repeats (LRR) and a succession of $\beta$ strands and $\alpha$ helices organized into a horseshoe shaped structure. FSH binds to the curved inner surface of the receptor ectodomain in a hand-clasp fashion and both $\alpha$ and $\beta$ beta subunits interact with the $\beta$ strands residues of the receptor. FSHR forms dimers, and the two hormone bound ectodomains interact with each other. Dimerization is associated with negative cooperativity of hormone binding (Costagliola et al., 2005; Urizar et al., 2005)

Two types of determinants for the receptor ectodomain have been proposed by mutagenesis and crystallographic studies (Smits et al., 2003; Vassart et al., 2004):

- Determinants in the LRR have been involved in specific interactions with the cognate ligand. Crystallization has provided structural evidence for the residues implicated in this recognition specificity at the atomic level of resolution (Fan \& Hendrickson, 2005a) and confirmed previous mutagenesis studies (Smits et al., 2003; Vassart et al., 2004).

- Negative determinants which restrict ligand-receptor interaction. They prevent hCG binding to the FSHR by electrostatic repulsive mechanisms, but have little effect on FSH binding. This hypothesis, formulated by Moyle (Moyle et al., 1994), has been supported by mutagenesis and structural studies (Costagliola et al., 2005; Fan \& Hendrickson, 2005a). 
GPCR fluctuate between inactive and active conformations (Vassart et al., 2004) ; in the absence of the ligand the receptor is in an inactive form which is stabilized by the unliganded ectodomain. Deletion of this ectodomain yields a constitutively activated receptor which is, however, not as fully active as the hormone-activated receptor. A two steps process has been proposed for the receptor shift towards the fully active form: binding of the ligand and induction of a transconformational change of the ectodomain; this latter change, confirmed by structural studies, would then affect protruding loops implicated in activating the transmembrane domain of the receptor (Vassart et al., 2004 ; Fan \& Hendrickson, 2005b).

The large FSH-R gene is situated on chromosome $2 \mathrm{p} 21$ and comprises ten exons (Minegishi et al., 1991).

While mutations of gonadotrophin genes are exceedingly rare, genetic alterations of their respective receptors are relatively more frequent and can cause a gain- or a loss of function. The receptor is constitutively active when carrying an activating mutation, independently of ligand binding (Themmen \& Huhtaniemi, 2000). Gain-offunction mutations have been mainly found in the transmembrane domain of glycoprotein hormone receptors but extracellular activating point mutations have also been reported (Vassart, 2004). Loss-of-function mutations are located in any region of the receptor and can cause either the suppression of hormone binding or abnormality in signal transduction. In case of-gain-of function mutations heterozygosity is sufficient to cause phenotypic variations and a dominant inheritance. However, loss-of-function mutations generally require homozigosyty for phenotypic changes ad are transmitted recessively. An exception has been described for dominant TSH receptor loss of function mutations (Beck-Peccoz et al., 
2006; Calebiro et al., 2005) but no dominant mutations have yet been found for the FSH receptor so far.

\section{ACTIVATING MUTATION OF THE FSH RECEPTOR:}

The only gain-of-function FSHR mutation has been described for a man hypophysectomized because of a pituitary tumor. This individual, despite undetectable serum gonadotrophin levels, had normal testis volume, spermatogenesis with normal semen parameters and fathered three children under testosterone substitution alone (Gromoll et al., 1996) This patient had a heterozygous activating mutation Asp567Gly in the third intracytoplasmatic loop of the $\mathrm{FSH}$ receptor. Basal c-AMP production in COS-7 cells transiently transfected with the mutated receptor was 1.5 -fold greater than in cells transfected with the wild type receptor. The search of other FSHR activating mutations in twin pregnancies or gonadal dysgenesis, ovarian tumors, precocious puberty, has been unsuccessful (de la Chesnaye et al., 2001; Giacaglia et al., 2000; Montgomery et al., 2001; Sundblad et al., 2004).

\section{Inactivating mutations of the FSHR:}

\section{Ovarian dysgenesis described in Finnish women}

The first inactivating FSHR mutation was found in several Finnish families after a genetic survey of women with hypergonadotrophic hypogonadism (Aittomaki et al., 1995). Twenty-two of the 72 patients studied carried an identical homozygous lossof-function Ala189Val mutation in the extracellular domain of the FSHR (Fig.1). Segregation analysis confirmed the autosomic recessive mode of inheritance for the 
disease. Genealogical studies showed a founder effect in an isolated subpopulation of north-eastern Finland and several families with two or more affected sisters were identified. The mutation was artificially concentrated in this population as a result of consanguinity. The homozygous patients (Finnish 1) (Table 1) presented with a phenotype described as ovarian dysgenesis. The main features of this disorder include hypergonadotrophic hypogonadism, primary amenorrhea, variable pubertal development, high gonadotrophins and low estrogen levels. Another characteristic of this phenotype was the presence of hypoplasic ovaries with impaired follicle growth. No functional responses were observed in vivo after treatment with high doses of recombinant FSH (Vaskivuo et al., 2002)

The histology of ovarian biopsies from nine patients showed atrophic gonads with dense collagen on the surface, and a low number of follicles. Primordial follicles were always present, 4 patients had primary follicles, two patients exhibited secondary follicles and only one had a mature follicle (Aittomaki et al., 1996).

Functional analysis showed that the mutated receptor was trapped inside the cell as only a weak expression at the cell surface was observed. However the Ala189Val mutation did not totally abolish ligand-induced signal transduction and downstream cellular responses. FSH stimulation of $\mathrm{KK}-1$ cells transfected with mutant hFSHR led to an 8-fold cAMP accumulation, compared with a 27-fold accumulation using similar cells expressing wild type hFSHR. Similar proportions were observed in the steroidogenic response to $\mathrm{FSH}$ stimulation. Progesterone production after $\mathrm{FSH}$ stimulation was 7-fold greater in cells expressing the mutant receptor and was 23fold greater using wild type hFSHR transfected cells. IP $\mathrm{P}_{3}$ production in response to FSH was significantly less than that observed in cells expressing mutant hFSHR: only 1.5-fold stimulation of $\mathrm{IP}_{3}$ accumulation was observed in cells transfected with 
the mutant hFSHR whereas it was 6-fold in cells transfected with the wild type receptor (Rannikko et al., 2002).

Detecting the first FSHR mutation permitted to establish an aetiology for the resistant ovary syndrome and provided the first step into understanding FSH action on ovarian function in the human separately from that of $\mathrm{LH}$. However in some cases follicular growth in Finnish patients progresses up to the antral stage which raises two questions:

1) Whether the Finnish phenotypes correspond to a complete inactivating mutation of FSHR, in view of the fact that the mutation did not completely abolish receptor function in vitro (Rannikko et al., 2002).

2) Which steps of folliculogenesis are under FSH control.

Several successive studies of cohorts of hypergonadotrophic ovarian dysgenesis patients showed that the Ala189Val mutation is absent or extremely rare in other countries outside Finland. Its frequency was determined from a total of 4981 samples from individuals in Finland, Switzerland, Denmark, and in the Chinese population of Singapore. The frequency of the mutation was $0.96 \%$ for all Finnish samples ( $n=1976)$, with a greater representation of the mutant allele in the northeastern part of the country. Only 1 mutation carrier was identified in the samples from Switzerland $(n=1162)$, whereas none were found in samples from Denmark $(n=1094)$ and the Singapore Chinese population $(n=540)$ (Jiang et al., 1998).

\section{Complete loss of function mutation of the FSH receptor}

In collaboration with $\mathrm{F}$ Kuttenn and $\mathrm{P}$ Touraine we studied a patient who presented a complete phenotype of FSHR inactivation (Paris1) (Table 1) (Meduri et al., 2003). 
This 26 years old woman consulted for infertility 18 months after discontinuing hormonal contraception which was started at seventeen. She had delayed puberty and a history of primary amenorrhea. She had elevated gonadotrophins, especially FSH (67 IU/I), very low estradiol and Inhibin B plasma levels and testosterone levels in the lower/normal range. At the examination she had osteoporosis, and hypoplasic uterus and ovaries. Family studies were not possible because the patient was adopted. We administered increasing doses of recombinant $\mathrm{FSH}$ over 21 days for ovarian stimulation (Total dose: 10200 IU of recombinant FSH). This did not modify estradiol, Inhibin B levels or the ovarian size and aspect at ultrasonography. A novel homozygous Pro519Thr mutation in the second intracellular loop of the receptor was detected. This mutated proline is highly conserved in the $\mathrm{FSH}, \mathrm{LH}$ and TSH receptors. Functional studies showed that the mutated receptor was unable to induce adenylate cyclase stimulation even at high FSH concentrations: Hormone binding was barely detectable $(6.3+/-1.6 \%)$ when compared to the wild type FSHR transfected cells. We performed immunofluorescence and confocal studies with a specific monoclonal anti-FSHR antibody. These studies demonstrated that the mutant receptor was not properly targeted to the cell surface and remained trapped intracellularly probably because of an altered conformation resulting from the mutation of the proline residue.

Histological examination of the ovarian biopsy (Fig 1-I) showed a normal surface epithelium and a superficial band of fibrous tissue under the albuginea as found in the Finnish patients cited above. Beneath this layer however, were many small follicles (1-I-A), apposed or grouped in nests, with a disposition similar to that observed in immature ovaries. Most follicles were at the primordial or intermediary stage with normally appearing oocytes surrounded by squamous or mixed cubic and 
squamous granulosa cells. Primary follicles, constituted by an oocyte surrounded by cubic granulosa cells and devoid of theca interna, represented $7 \%$ of the total follicular population (1-I-B). Secondary follicles were absent. There was a total block of follicular maturation beyond the primary stage. The follicular density studied by image analysis in the ovarian specimen was of $24.2+/-4.6$ per $\mathrm{mm}^{2}$ this value was markedly more elevated than in age-matched women (Lass et al., 1997; Poirot et al., 2002) and similar to that observed in prepubertal ovaries (Block, 1951).

Immunohistochemical analysis showed that the ovarian specimens were devoid of steroidogenic enzymes. Labelling with PCNA showed similar expression levels in oocytes and granulosa cells as that observed in normal cycling gonads (1-I-C) More than two thirds of oocytes expressed the tyrosine-kinase c-Kit receptor (1-I-D,) similar to that obtained in normal control ovaries. No apoptosis was detected by the 3'-end labelling method (Not shown).

Thus primordial intermediary and primary follicles of this patient appeared to contain healthy oocytes and to be capable of proliferation.

However, no more developed follicles, were present. No steroidogenic cells were detectable in this biopsy, which is the logical consequence of the arrested follicular growth at the primary stage. A sterodogenic theca interna starts forming at a more advanced stage of follicular development, and becomes detectable only in secondary follicles with at last three layers of granulosa cells (Magoffin, 2005).

\section{Lessons derived from studying a complete molecular alteration of the human FSHR in vivo:}


Firstly, colonization of the primitive gonad by ovogonies and formation of primordial follicles in the fetal ovary is possible in the human, even in absence of FSH activity, as in mice with FSHR inactivation (Dierich et al., 1998).

Secondly, follicle development in the cycling human ovary has classically been subdivided into "basal" and "hormone-dependent". The limits between both periods vary according to the study and the species under observation: FSH In women is thought to intervene in follicular maturation and selection starting from the late preantral or early antral stage whereas growth from primordial to late preantral stages is thought to be gonadotropin-independent (Campbell et al., 2003; Erickson \& Shimasaki, 2001; Zeleznik, 2004)

These traditional notions have been strengthened by observations in genetically modified mice deficient of FSHR. The female rodents do not ovulate and are therefore sterile, but exhibit well grown, multilayered secondary follicles, and maturation can proceed up to the preantral stage. Hypertrophied interstitial cells with lipid droplets, resembling steroidogenic cells have been detected in the ovaries of FSHR-/- mice (Dierich et al., 1998). The presence of these steroidogenic secondary interstitial cells suggests that follicular development, even in absence of FSH action, is sufficiently advanced for the formation of a functional theca. Well developed secondary follicles are also found in FSH $\beta$ gene female knock-out mice ((Kumar et al., 1997) Therefore early follicular growth up to the stage of secondary follicles and formation of a functional theca interna is independent of $\mathrm{FSH}$ in mice.

By contrast FSH appears to be critical for follicular maturation beyond the primary stage in humans. This was observed in our study of the patient with a complete loss-of-function FSHR mutation (Meduri et al., 2003) and is different from what observed in genetically modified mouse models. Our patient did not develop follicles 
beyond the primary stage, when a monolayer of cubic granulosa cells surrounds the oocyte and the theca interna has not yet formed. The passage from primary to secondary follicle, characterized by a multilayered membrana granulosa and a theca interna, was thus impaired in this woman with a total loss of FSHR function. This stage of follicular development from primary to secondary follicle was believed to be independent of FSH in the human (Campbell et al., 2003; Erickson \& Shimasaki, 2001; Zeleznik, 2004)). Follicular FSHR expression starting from the intermediaryprimary stages had also been shown by immunohistochemistry with monoclonal anti FSHR antibodies (Meduri et al., 2002). However it was not established whether the receptor was functional at this early follicular stage in humans.

The failure of follicular development beyond the primary stage in a patient with a completely inactivating FSHR mutation demonstrates the importance of FSH action in follicular development starting from the earliest stages. These differences in ovarian histology and function between genetically modified rodents and humans with inactivated FSHR warrant particular prudence when extrapolating observations from rodent reproduction to humans.

Our findings demonstrate that FSH resistance causes infertility which is remarkably associated with the persistence of a large number of small follicles in the ovaries. This is probably due to a low follicular recruitment, as observed in prepubertal ovaries. This observation might lead to novel therapeutic approaches in the future with the development of novel techniques of in vitro follicular maturation.

\section{Loss of function mutations of the FSHR in men:}

Five men homozygous for the Ala 189 Val mutation were identified in the Finnish families cited above. The patients had a normal pubertal development but had 
moderately or slightly decreased testicular volume. Two patients generated two offspring each. They had normal plasma testosterone, normal to elevated LH levels, but high FSH. None of the patients had azoospermia, however all showed variable spermatogenic failure between severely and moderately reduced sperm counts or low volumes of sperm fluid with normal sperm concentrations. One patient had teratozoospermia. Studies of these individuals showed that FSH action is required for a normal spermatogenesis but is not critical for male fertility (Aittomaki et al., 1996)

To date, three male patients with FSH $\beta$-subunit mutations have been described. Two of these patients, who harbored distinct homozygous mutations Cys82Arg (Lindstedt et al., 1998) and Tyr76X (Layman et al., 2002) respectively, presented with small testes, azoospermia, and normal testosterone levels. The only individual with an available testicular histology was the latter, sibling of a woman who also had a homozygous Tyr76X nonsense mutation in the FSHß gene. He was a 30 -yr-old, 170-cm-tall infertile male, had a normal puberty, normal adult male testosterone levels, normal erections and ejaculation (12 cc) and no gynecomastia. However, this male patient had small testes and azoospermia. A testicular biopsy revealed Leydig cell hyperplasia and sparse, small seminiferous tubules with germinal cell aplasia, peritubular fibrosis, and few Sertoli cells (Layman et al., 2002) The third male patient, with a Val61X mutation, presented with absence of pubertal development, low testosterone levels, small testes, and azoospermia. (Phillip et al., 1998) This phenotype with azoospermia is at variance with the male phenotype caused by FSH receptor mutations in which fertility is maintained despite a decreased sperm quality (Aittomaki et al., 1995) 
The reasons for this discrepancy between observations of men deficient for $\mathrm{FSH}$ and for FSHR function remains unclear. The persistence of a residual function of the Ala189Val FSHR mutant in vivo in the Finnish patients cannot be excluded, since such a residual function was detected in vitro by Rannikko and co-workers (Rannikko et al., 2002). The mutated receptor may not sufficiently promote follicular growth in women but might be able to sufficiently sustain spermatogenesis in men. Another explanation for the distinct phenotypes observed may be that other factors may influence the phenotypic expression of $\mathrm{FSH} \beta$ defects. These individuals may have additional functional defects resulting in the absence of spermatogenesis leading to infertility. Identifying and studying supplementary patients that have complete loss-of-function FSHR mutations and FSH $\beta$ defects is warranted and may help to clarify this topic.

\section{Animal models with inactivated FSH $\beta$ and FSHR}

The FSHR-null (FSHRKO) male mice have been described by two separate laboratories (Abel et al., 2000; Dierich et al., 1998). They have delayed puberty (Krishnamurthy et al., 2001), low Leydig cell number, low serum testosterone levels and small testis size, however they are fertile.

Male mice deficient for the $\mathrm{FSH}-\beta$ gene have normal sexual development, normal $\mathrm{LH}$ levels, decreased testicular volume, a sharp decrease of sperm numbers $(75 \%)$ and are also fertile. Microscopic examination of the testes reveals a relative diminution in all testicular elements, but Leydig cell numbers and progression through spermatogenesis appear to be normal (Kumar et al., 1997). The reintroduction of the $\mathrm{FSH}-\beta$ gene in these genetically modified animals causes a complete reversion of the phenotype (Kumar et al., 1998). 
The discordances between the two genetically modified rodent models concern essentially androgen production. In FSHRKO mice Leydig cell number is reduced to $60 \%$ of the normal value (Abel et al., 2000; Dierich et al., 1998) whereas Leydig cell number and function appear normal in FSHßKO mice. Consequently, circulating testosterone levels are reduced in FSHRKO mice but are normal in adult FSHßKO mice. This difference may be explained by the presence of a constitutive activity within the FSHR in the absence of ligand (Baker et al., 2003). G Protein-coupled receptors can display constitutive activity (de Ligt et al., 2005; Vassart et al., 2004) The constitutively activated FSHR may stimulate Sertoli cells production of tropic factors acting on Leydig cells function and proliferation. Previous studies have demonstrated $\mathrm{FSH}$ effects on Leydig cell activity and function (O'Shaughnessy et al., 1992; Vihko et al., 1991).

\section{Partial loss of function mutation of the FSHR}

Studying other glycoprotein hormone receptors, LHR and TSHR, has demonstrated the existence of partial mutations, associated with a less severe phenotype (Kopp et al., 1995; Latronico et al., 1996; Misrahi et al., 1997). These partial phenotypes may be more frequent that those resulting from a complete alteration of receptor function. From these observations we suggested that there are cases in which the mutated FSHR is not completely inactive. We thus extended our analysis to a cohort of infertile women with partial follicular growth. We detected two patients with FSHR mutations resulting in a partial loss of function associated with a novel phenotype (Beau et al., 1998; Touraine et al., 1999).

The patients were 19 (Paris 2) and 30 (Paris 3) years old, and consulted for primary and secondary amenorrhea respectively (Table 1). Both had non consanguineous 
parents. At examination they had normal pubertal development and secondary sexual characters. Hormonal assays revealed high gonadotrophins, subnormal estradiol and normal to elevated testosterone levels. In contrast with the elevated gonadotrophins, both patients had normal-sized ovaries, which was a marked difference from the previously described phenotype. Furthermore the ovaries of both patients included large growing follicles by ultrasonography. Paris 2 had about a dozen of follicles up to $3 \mathrm{~mm}$ in diameter and Paris 3 had several antral follicles up to $5 \mathrm{~mm}$. Ovarian stimulation of Paris 3 with recombinant FSH caused a partial response with an elevation of circulating estradiol and an increase in follicular diameter from 5 to $8,5 \mathrm{~mm}$. However no changes in plasmatic estradiol and inhibin levels and in the aspect of the ovaries at ultrasonography were observed in Paris 2 after administering high doses of recombinant FSH. Thus the clinical phenotype of Paris 2 was more severe than that of Paris 3

Paris 2 had a Leu601Val substitution in the third extracellular loop of the receptor and an Asp224Val mutation in the extracellular domain (Fig 2B). Each parent of the patient was heterozygous for one of the mutations. Paris 3 was a compound heterozygote with an Arg573Cys mutation in the third intracellular loop of the receptor and an lle160Thr mutation in the extracellular domain (Fig 2B). The father and unaffected sister were heterozygous for the Arg573Cys mutation while the mother carried the lle160Thr mutation.

Functional studies (Fig. 2C) revealed that mutant receptors of Paris 2 stimulated adenylate cyclase less than the wild type FSHR: about $\sim 12 \%$ (Leu601Val) and about $\sim 4 \%$ (Asp224Val). Mutant receptors function in Paris 3 was less impaired: about $\sim 24 \%$ (Arg573Cys) and about 9 \% (Ile160Thr) c-AMP accumulation when compared to the wild type FSHR. Thus the total residual receptor function of both 
alleles of the FSHR was more altered in the case of Paris 2 than in Paris 3 (Fig 2C and Table 1). The first mutant in each case had a normal expression at the cell surface and displayed an altered signal transduction whereas the second mutant had altered targeting to the cell surface and altered FSH binding.

Histological studies of the ovaries of both patients showed normal primordial, primary and secondary follicles and few small antral follicles which reached a maximum diameter of $3 \mathrm{~mm}$ in Paris 2 and $5 \mathrm{~mm}$ in Paris 3 (Fig 1-II and 1-III).

The antral follicles of both patients, with the exception of their size, had a similar histology characterized by a hypertrophic theca interna, and the presence of granulosa cells at various stages of degeneration (Fig1-II-G, III-K).

Immunohistochemical studies revealed that a $5 \mathrm{~mm}$ antral follicle in the ovary of Paris 3 had a hypertrophic theca interna expressing $\mathrm{LH}$ receptors and the steroidogenic enzymes $3 \beta$ HSD and P450c17a (not shown). The granulosa cells of this same follicle expressed FSHR but were devoid of P450 Aromatase (not shown). The thecal cells of the antral follicles of both patients were always strongly immunopositive for 3ßHSD (not shown) and P450c17a (Fig.1-II-H, III-L). Oocytes in the developing follicles expressed the tyrosine kinase receptor c-Kit (not shown). Some oocytes and granulosa cells of the small follicles also expressed the proliferation marker PCNA (not shown). The residual FSHR function in these two patients could sustain follicular development up to early antral stages, however a functional dissociation between the two main follicular cellular subpopulations was observed. Theca interna cells, stimulated by high LH levels, were capable of androgen synthesis, and became hypertrophic. Granulosa cells, deprived of adequate FSH stimulation did not mature and follicular development did not progress further. The antral follicular growth stage was dissimilar for these two 
patients with partial loss of function of the mutated FSHR: Paris 3, with the less severe loss of function, had larger $(5 \mathrm{~mm})$ follicles at ultrasonography (Fig. 2A) than Paris 2 (3 $\mathrm{mm})$ (not shown). These findings demonstrate a correlation between the clinical and ovarian phenotypes and the degree of alteration of receptor function in patients with loss of function mutations of the FSHR (Table 1 and Figure 2C).

These observations thus resulted in a greater understanding of the role of FSH in ovarian follicular maturation and particularly during early antral development in humans; few models are available to analyse this step of follicular development. It is thought by many that basal levels of gonadotrophins are required for the growth of follicles from the preantral to the selectable stage (Campbell et al., 2003; Erickson \& Shimasaki, 2001; Zeleznik, 2004) whereas our observations strongly suggest that incremental levels of $\mathrm{FSH}$ or of receptor function are required for the normal growth of early antral follicles, before selection. If this cannot be achieved, the development of antral follicles stops and the maximal size reached is indicative of the degree of residual FSHR function. By contrast, after selection, the growth of the dominant follicle can proceed to the ovulatory stage even in presence of decreasing $\mathrm{FSH}$ levels (Zeleznik, 2004). Other patients that have partial loss of FSHR function may display even milder phenotypes than those described here, with more developed follicles. The presence of numerous reserve follicles in the ovaries of these women may allow a treatment of their infertility in the future by novel techniques of in vitro maturation, possibly using culture mediums with a high content of recombinant FSH associated with steroids and growth factors. Although gonadotropins are essential in regulating follicular development, several locally produced growth and endocrine factors amplify FSH action by autocrine and paracrine mechanisms (Reviewed in: Demesteere et al., 2005). Complete oocyte development in vitro from primordial 
follicles of newborn mouse ovaries has been achieved even after growth in medium supplemented with epidermal growth factor alone without FSH (Eppig \& O'Brien, 1996).

Even if prolonged follicular development of small human follicles in culture has not been yet achieved, possibly owing to the extended growing period, novel techniques of oocyte growth and acquisition of meiotic competence are being developed in big mammals (reviewed in: Miyano \& Manabe, 2007; Hutt et al., 2007), these new technologies may provide in the future solutions to the infertility of patients with a persistent follicular reserve.

\section{Additional reported FSHR mutations.}

Two other cases were described (Fig. 2B). One report was of a 17 years woman with compound heterozygous mutations of Ala189Val in the extracellular domain and Ala419Thr in the second transmembrane stretch. This patient presented a phenotype slightly less severe than that of the Finnish patients described above. (Doherty et al., 2002). This woman had primary amenorrhea and low estrogen levels but her secondary sex characteristics and signs of endometrial estrogenic stimulation were normal at transvaginal ultrasonography. The mutated Ala419Thr receptor was capable of binding $\mathrm{FSH}$ but was not capable of signal transduction in vitro.

Another FSHR mutation was described for a hypergonadotrophic woman with delayed puberty and primary amenorrhea: she carried a Pro348Arg substitution in the extracellular part of exon 10 just outside the transmembrane domain of the receptor protein (Allen et al., 2003). The mutation completely abolished hormone binding. The possible intracellular sequestration of the receptor was not 
investigated. No ovarian biopsies were available for either patient, thus no correlation was possible between the mutated receptor function and ovarian histology.

Studies of patients with FSH-R loss-of-function mutations have led to the conclusion that female fertility is critically dependent on $\mathrm{FSH}$ function whereas male fertility is less affected (Layman et al., 2002; Huhtaniemi, 2002; Themmen, 2005). The study of supplementary patients is necessary before more precise conclusions can be drawn.

\section{II- BROADENING SPECIFICITY OF THE FSH RECEPTOR:}

Ovarian hyperstimulation syndrome (OHSS) can spontaneously arise during pregnancy and is quite rare (Budev et al., 2005) but most often is a iatrogenic complication of ovarian stimulation treatments with ovulation drugs for in vitro fertilization (IVF) (0.5 to 5\% of IVF) (Budev et al., 2005; Kaiser, 2003). OHSS can be a potential life-threatening complication in IVF. It is due to an increase of capillary permeability under the action of one or several vasoactive ovarian factors (GarciaVelasco \& Pellicer, 2003) which is responsible for the fluid-shift from the vascular bed to the extravascular space. Extravasations of fluid to the abdominal cavity may provoke ascites, hypovolemia and hemoconcentration.

The incidence of this syndrome is thought to be underestimated.

Ovarian hyperstimulation arising during a spontaneous pregnancy (in untreated women) may be isolated or associated with other symptoms. It may lead to abortion or premature delivery. Some familial cases have been described and suggest a genetic etiology (Di Carlo et al., 1997) Contrasting with the usual block of ovarian folliculogenesis observed during pregnancy, the ovary is filled with growing follicles. 
Different etiologies of the syndrome have been discussed as the association with a previously undetected polycystic ovary syndrome (Zalel et al., 1995), alterations of the prorenin-renin-angiotensin system (Di Carlo et al., 1997) disturbed liver function altering hormonal balance (Lipitz et al., 1996) Cross-stimulation of the FSHR by high concentrations of heterologous ligands of the pituitary glycoprotein hormone family has also been implicated; this is because OHSS may occur in profound hypothyroidism (Nappi et al., 1998) or in trophoblastic diseases like molar pregnancies (Ludwig et al., 1998) characterized by high TSH or hCG concentrations, respectively.

However, the association of OHSS with high hormone concentrations is not constant and an ovarian hypersensitivity to gonadotrophins has also been suggested. This has not been demonstrated and the pathogenesis of the syndrome remains unknown.

\section{Clinical study of a familial spontaneous OHSS}

We had the opportunity to study a familial case of OHSS (Vasseur et al., 2003) (Fig. 3) The proband was a multiparous 25-year-old woman of Moroccan origin, who had experienced OHSS during all previous pregnancies but one. She reported regular menses between pregnancies. The presence of bilateral multilocular ovarian masses and ascites was noted at the time of ultrasonography during the first pregnancy, and a therapeutic abortion was performed at 8 weeks of gestation. Laparoscopy, performed 21 days after abortion, confirmed the presence of a moderate amount of ascitic fluid and large multicystic ovaries.

Her second pregnancy ended in a miscarriage at 6 weeks, without evidence of OHSS. During the third pregnancy, OHSS presented at 8 weeks of gestation and 
lasted till childbirth. She delivered a small for gestational age female baby. The $4^{\text {th }}$ pregnancy, also complicated by OHSS, was terminated by therapeutic abortion at 9 weeks.

This patient consulted at the eighth week of her $5^{\text {th }}$ spontaneous pregnancy with acute lower abdominal pain and nausea. Ultrasonography revealed enlarged ovaries measuring $14 \mathrm{~cm}$ in length, with multiple cysts and normal stroma (Fig. 3A) Serum levels of CG $\beta$ subunit were normal. As expected during pregnancy, serum levels of FSH were very low. Estradiol levels exceeded the upper limit of the normal range during the $1^{\text {st }}$ trimester. Inhibin B levels were markedly elevated, which is rather surprising for a marker of $\mathrm{FSH}$ action especially in presence of $\mathrm{FSH}$ suppression. Furthermore, there was a striking parallelism between the evolution of hCG and inhibin B serum levels, whose maximum values were observed during the first trimester (Fig. 4).

Other biological assays, including those related to thyroid function, were normal. The patient delivered a normal female infant.

Familial anamnesis showed that two of the patient's sisters had reported similar symptoms (Fig. 3B). In one sister, the syndrome had occurred only during the last four of her 7 pregnancies and always during the first trimester. A laparotomy, performed during the $4^{\text {th }}$ pregnancy, showed enlarged ovaries and ascites.

The other affected sister had moderate ovarian hyperstimulation syndrome during the last two of her four pregnancies. On each occasion, enlarged ovaries and ascites were detected by laparotomy. She had bilateral resection of two large ovarian wedges during the first laparotomy, but the syndrome relapsed and another laparotomy during the subsequent pregnancy showed enlarged ovaries. 
An ovarian biopsy from an affected sister was histologically studied (Fig. 3C). It was consistent with hyperreactio luteinalis, a pathologic feature of OHSS (Schnorr et al., 1996) Indeed, multiple serous and hemorrhagic follicular cysts were found. The cyst lining was composed of several layers of luteinized granulosa and theca cells. This early luteinization is indicative of stimulation of both $\mathrm{LH}$ and $\mathrm{FSH}$ receptors.

A third sister had two normal pregnancies; the other members of the family declined to be interviewed. All these elements were strongly in favor of a genetic etiology.

\section{Molecular and functional studies}

The unusual and excessive follicular recruitment during pregnancy observed in this patient, associated with the increase in estradiol and inhibin B plasma levels, strongly suggested FSH receptor activation, even though suppressed FSH plasma levels were observed.

We sequenced the FSHR gene to further understand this activation. We found a heterozygous substitution in exon 10, encoding a Thr449lle mutation surprisingly located in the transmembrane domain of the receptor (Vasseur et al., 2003). The mutation corresponded to a residue present in a highly conserved motif in $\mathrm{FSH}$, TSH and LH receptors. A correlation between the phenotype and the genotype was found in the family, as the mutation was present in both affected sisters, but was not found in the other unaffected female sibling (Figure 3B).

Functional expression of the mutated receptor in vitro showed no difference in the response to recombinant $\mathrm{FSH}$ between the wild-type and mutated receptors: both had similar dissociation constants, maximal binding capacities, and EC50 (dose of hormone producing half maximal effect) values. 
The mutant responded to hCG with a dose dependent increase in CAMP, in contrast to the wild-type LH receptor. The EC50 was also markedly higher than the EC50 of the $\mathrm{LH}$ receptor.

This effect shows a broadening of the specificity of the FSH receptor for hCG at high concentrations of the hormone, such as are found during pregnancy. This increased sensitivity of the FSH receptor to hCG explains the paradoxical activation of the FSH receptor during pregnancy by the elevated chorionic gonadotrophins and the occurrence of OHSS.

\section{Models proposed:}

The effect of a mutation of a highly conserved residue located in the transmembrane domain of the receptor on the specificity of hormone binding was unexpected. The specificity of hormone binding is dependent on the LRR located in the extracellular domain of the receptor. Thus, we would have expected the mutation to be situated in the extracellular domain of the FSHR. Moreover, a spontaneous mutation in the ectodomain of the TSHR results in a greater specificity toward hCG (Rodien et al., 1998) causing a familial case of spontaneous gestational thyrotoxicosis. As expected, the mutation affected a residue in the LRR portion of the ectodomain of the TSHR. Moreover, engineered mutations of specific residues of the ectodomain in the LRR of pituitary glycoprotein hormone receptors lead to promiscuous activation by a different ligand (Smits et al., 2003)

Other cases of OHSS associated with FSHR receptor mutations have also been described, (Figure 5) \{Smits, 2003\}(De Leener et al., 2006; Montanelli et al., 2004) All the reported mutations are found in the transmembrane domain of the receptor. In two cases they correspond to various substitutions of the same residue. These 
mutations broaden the FSHR specificity for $\mathrm{TSH}$, with constitutive receptor activation.

Various models of glycoprotein hormone receptor activation have been proposed. A two-step process has been proposed with the initial binding of the ligand to the ectodomain and the subsequent activation of the receptor transmembrane domain. One model involves hormone-induced conformational changes in the extracellular domain that are transmitted to the transmembrane domain for activation (Braun et al., 1991; (Fan \& Hendrickson, 2005b) The mutation found in OHSS may induce a conformational change in the transmembrane domain. This conformation may be, in a reciprocal way, transmitted to the ectodomain, possibly weakening its negative determinants (Meng \& Bourne, 2001) thus challenging receptor specificity.

Deletion of the TSHR ectodomain results in an increased constitutive activity of the receptor (Zhang et al., 2000; Quellari et al., 2003; Vlaeminck-Guillem et al., 2002). This suggests that, in the unbound receptor, the ectodomain plays an inhibitory role on the transmembrane domain, which is released upon hormone binding. A second model was thus proposed in which hormone binding switches the ectodomain from a tethered inverse agonist to a full agonist of the transmembrane domain of the receptor (Vassart et al., 2004). The mutations found in OHSS may also decrease, to different degrees, the inhibitory constraint normally present in the transmembrane domain of all G protein coupled receptors (Costagliola et al., 2005). This decrease in the inhibitory constraint may allow low-affinity interactions between the ectodomain and a heterologous ligand, inducing an active conformation of the transmembrane domain of the receptor.

\section{Applications in the management of iatrogenic OHSS}


Inappropriate FSHR stimulation by hCG can trigger OHSS symptoms. A similar mechanism may be involved in the more frequent iatrogenic syndrome, in which exogenous hormones are used. The susceptibility to iatrogenic ovarian hyperstimulation may be associated with FSHR gene polymorphisms and, therefore, with the hypersensitivity of FSHR alleles to exogenous hormones. This may explain why women display various susceptibilities to OHSS under identical pharmacological protocols.

The ovarian response to FSH stimulation was reported to depend on the FSHR genotype (Perez Mayorga et al., 2000). This led to the suggestion that allelic variants have slightly different activities in vivo. FSH receptor polymorphisms have no discernible effect on FSH receptor function in vitro (Sudo et al., 2002). Individuals that responded poorly to ovarian stimulation had a higher prevalence of the Ser680 allele (de Castro et al., 2003). In other studies, genotype at position 680 was not predictive of OHSS development but an association was detected between severity of symptoms in iatrogenic OHSS and the FSHR Ser680Asn polymorphism (D'Alva et al., 2005; Daelemans et al., 2004). We may however question why the allele associated with poor responders to ovarian stimulation (de Castro et al., 2003; Perez Mayorga et al., 2000) was enriched in the severe OHSS population (Daelemans et al., 2004). The FSHR Ser680/Ser680 genotype was associated with higher ovarian thresholds to FSH and longer menstrual cycles (Greb et al., 2005). The Ser680 allele was also more prevalent in subfertile patients with a regular menstrual cycle and elevated FSH (de Koning et al., 2006).

Supplementary cohort studies are needed before we know if these observations have a clinical impact in the management of patients undergoing IVF protocols (Behre et al., 2005; de Castro et al., 2005; Delbaere, 2006; Delbaere et al., 2006). 
The description of molecular alterations of the $\mathrm{FSH}$ receptor has led to the identification of the aetiology of previously described syndromes. It also highlights residues important for receptor function and allows proposing new models of receptor function. The physiological role of FSH in the humans is better understood because of the in vivo study of the consequences of impaired FSHR function. However it is important to correlate the patients' phenotypes to studies of residual receptor function in vitro possibly performed in several different laboratories. Differences with animal models have also been revealed and must be taken into consideration before drawing conclusions about the human species.

\section{References}

Abel, M.H., Wootton, A.N., Wilkins, V., Huhtaniemi, I., Knight, P.G. \& Charlton, H.M. (2000). The effect of a null mutation in the follicle-stimulating hormone receptor gene on mouse reproduction. Endocrinology, 141, 1795-803.

Aittomaki, K., Herva, R., Stenman, U.H., Juntunen, K., Ylostalo, P., Hovatta, O. \& de la Chapelle, A. (1996). Clinical features of primary ovarian failure caused by a point mutation in the follicle-stimulating hormone receptor gene. J Clin Endocrinol Metab, 81, 3722-6.

Aittomaki, K., Lucena, J.L., Pakarinen, P., Sistonen, P., Tapanainen, J., Gromoll, J., Kaskikari, R., Sankila, E.M., Lehvaslaiho, H., Engel, A.R., Nieschlag, E., Huhtaniemi, I. \& de la Chapelle, A. (1995). Mutation in the follicle-stimulating hormone receptor gene causes hereditary hypergonadotropic ovarian failure. Cell, 82, 959-68.

Allen, L.A., Achermann, J.C., Pakarinen, P., Kotlar, T.J., Huhtaniemi, I.T., Jameson, J.L., Cheetham, T.D. \& Ball, S.G. (2003). A novel loss of function mutation in exon 10 of the FSH receptor gene causing hypergonadotrophic hypogonadism: clinical and molecular characteristics. Hum Reprod, 18, 251-6.

Baird, D. (2006). [Role of FSH and LH in follicle development]. J Gynecol Obstet Biol Reprod (Paris), 35, 2S24-2S29.

Baker, P.J., Pakarinen, P., Huhtaniemi, I.T., Abel, M.H., Charlton, H.M., Kumar, T.R. \& O'Shaughnessy, P.J. (2003). Failure of normal Leydig cell development in folliclestimulating hormone (FSH) receptor-deficient mice, but not FSHbeta-deficient mice: role for constitutive FSH receptor activity. Endocrinology, 144, 138-45.

Beau, I., Touraine, P., Meduri, G., Gougeon, A., Desroches, A., Matuchansky, C., Milgrom, E., Kuttenn, F. \& Misrahi, M. (1998). A novel phenotype related to partial loss of function mutations of the follicle stimulating hormone receptor. J Clin Invest, 102, $1352-9$. 
Beck-Peccoz, P., Persani, L., Calebiro, D., Bonomi, M., Mannavola, D. \& Campi, I. (2006). Syndromes of hormone resistance in the hypothalamic-pituitary-thyroid axis. Best Pract Res Clin Endocrinol Metab, 20, 529-46.

Behre, H.M., Greb, R.R., Mempel, A., Sonntag, B., Kiesel, L., Kaltwasser, P., Seliger, E., Ropke, F., Gromoll, J., Nieschlag, E. \& Simoni, M. (2005). Significance of a common single nucleotide polymorphism in exon 10 of the follicle-stimulating hormone (FSH) receptor gene for the ovarian response to FSH: a pharmacogenetic approach to controlled ovarian hyperstimulation. Pharmacogenet Genomics, 15, 451-6.

Block, E. (1951). Quantitative morphological investigations of the follicular system in women; methods of quantitative determinations. Acta Anat (Basel), 12, 267-85.

Budev, M.M., Arroliga, A.C. \& Falcone, T. (2005). Ovarian hyperstimulation syndrome. Crit Care Med, 33, S301-6.

Burns, K.H., Yan, C., Kumar, T.R. \& Matzuk, M.M. (2001). Analysis of ovarian gene expression in follicle-stimulating hormone beta knockout mice. Endocrinology, 142, 2742-51.

Calebiro, D., de Filippis, T., Lucchi, S., Covino, C., Panigone, S., Beck-Peccoz, P., Dunlap, D. \& Persani, L. (2005). Intracellular entrapment of wild-type TSH receptor by oligomerization with mutants linked to dominant TSH resistance. Hum Mol Genet, 14, 2991-3002.

Campbell, B.K., Souza, C., Gong, J., Webb, R., Kendall, N., Marsters, P., Robinson, G., Mitchell, A., Telfer, E.E. \& Baird, D.T. (2003). Domestic ruminants as models for the elucidation of the mechanisms controlling ovarian follicle development in humans. Reprod Suppl, 61, 429-43.

Costagliola, S., Urizar, E., Mendive, F. \& Vassart, G. (2005). Specificity and promiscuity of gonadotropin receptors. Reproduction, 130, 275-81.

d'Alva, C.B., Serafini, P., Motta, E., Latronico, A.C. \& Mendonca, B.B. (2005). Letter re: FSH receptor polymorphisms and iatrogenic ovarian hyperstimulation. $J$ Clin Endocrinol Metab, 90, 4978; author reply 4978-9.

Daelemans, C., Smits, G., de Maertelaer, V., Costagliola, S., Englert, Y., Vassart, G. \& Delbaere, A. (2004). Prediction of severity of symptoms in iatrogenic ovarian hyperstimulation syndrome by follicle-stimulating hormone receptor Ser680Asn polymorphism. J Clin Endocrinol Metab, 89, 6310-5.

de Castro, F., Moron, F.J., Montoro, L., Real, L.M. \& Ruiz, A. (2005). Pharmacogenetics of controlled ovarian hyperstimulation. Pharmacogenomics, 6, 629-37.

de Castro, F., Ruiz, R., Montoro, L., Perez-Hernandez, D., Sanchez-Casas Padilla, E., Real, L.M. \& Ruiz, A. (2003). Role of follicle-stimulating hormone receptor Ser680Asn polymorphism in the efficacy of follicle-stimulating hormone. Fertil Steril, 80, 571-6.

de Koning, C.H., Benjamins, T., Harms, P., Homburg, R., van Montfrans, J.M., Gromoll, J., Simoni, M. \& Lambalk, C.B. (2006). The distribution of FSH receptor isoforms is related to basal FSH levels in subfertile women with normal menstrual cycles. Hum Reprod, 21, 443-6.

de la Chesnaye, E., Canto, P., Ulloa-Aguirre, A. \& Mendez, J.P. (2001). No evidence of mutations in the follicle-stimulating hormone receptor gene in Mexican women with 46,XX pure gonadal dysgenesis. Am J Med Genet, 98, 125-8.

De Leener, A., Montanelli, L., Van Durme, J., Chae, H., Smits, G., Vassart, G. \& Costagliola, S. (2006). Presence and absence of follicle-stimulating hormone receptor mutations provide some insights into spontaneous ovarian hyperstimulation syndrome physiopathology. J Clin Endocrinol Metab, 91, 555-62.

de Ligt, R.A., Rivkees, S.A., Lorenzen, A., Leurs, R. \& AP, I.J. (2005). A "locked-on," constitutively active mutant of the adenosine A1 receptor. Eur J Pharmacol, 510, 1-8. 
Delbaere, A., Smits, G., Vassart, G. \& Costagliola, S. (2006). Genetic predictors of ovarian hyperstimulation syndrome in women undergoing in vitro fertilization. Nat Clin Pract Endocrinol Metab, 2, 590-1.

Demeestere, I., Centner, J., Gervy, C., Englert, Y. \& Delbaere, A. (2005) Reproduction, 130 $147-156$

Di Carlo, C., Bruno, P., Cirillo, D., Morgera, R., Pellicano, M. \& Nappi, C. (1997). Increased concentrations of renin, aldosterone and $\mathrm{Ca} 125$ in a case of spontaneous, recurrent, familial, severe ovarian hyperstimulation syndrome. Hum Reprod, 12, 2115-7.

Dierich, A., Sairam, M.R., Monaco, L., Fimia, G.M., Gansmuller, A., LeMeur, M. \& SassoneCorsi, P. (1998). Impairing follicle-stimulating hormone (FSH) signaling in vivo: targeted disruption of the FSH receptor leads to aberrant gametogenesis and hormonal imbalance. Proc Natl Acad Sci U S A, 95, 13612-7.

Doherty, E., Pakarinen, P., Tiitinen, A., Kiilavuori, A., Huhtaniemi, I., Forrest, S. \& Aittomaki, K. (2002). A Novel mutation in the FSH receptor inhibiting signal transduction and causing primary ovarian failure. J Clin Endocrinol Metab, 87, 11515.

Eppig, J.J. \& O'Brien M.J. (1996) Development in vitro of mouse oocytes from primordial follicles. Biol Reprod, 54, 197-207.

Erickson, G.F. \& Shimasaki, S. (2001). The physiology of folliculogenesis: the role of novel growth factors. Fertil Steril, 76, 943-9.

Fan, Q.R. \& Hendrickson, W.A. (2005a). Structural biology of glycoprotein hormones and their receptors. Endocrine, 26, 179-88.

Fan, Q.R. \& Hendrickson, W.A. (2005b). Structure of human follicle-stimulating hormone in complex with its receptor. Nature, 433, 269-77.

Garcia-Velasco, J.A. \& Pellicer, A. (2003). New concepts in the understanding of the ovarian hyperstimulation syndrome. Curr Opin Obstet Gynecol, 15, 251-6.

Giacaglia, L.R., Kohek, M.B.d.F., Carvalho, F.M., Fragoso, M.C., Mendonca, B. \& Latronico, A.C. (2000). No evidence of somatic activating mutations on gonadotropin receptor genes in sex cord stromal tumors. Fertil Steril, 74, 992-5.

Greb, R.R., Grieshaber, K., Gromoll, J., Sonntag, B., Nieschlag, E., Kiesel, L. \& Simoni, M. (2005). A common single nucleotide polymorphism in exon 10 of the human follicle stimulating hormone receptor is a major determinant of length and hormonal dynamics of the menstrual cycle. J Clin Endocrinol Metab, 90, 4866-72.

Gromoll, J., Simoni, M. \& Nieschlag, E. (1996). An activating mutation of the folliclestimulating hormone receptor autonomously sustains spermatogenesis in a hypophysectomized man. J Clin Endocrinol Metab, 81, 1367-70.

Huhtaniemi, I.T. (2002). LH and FSH receptor mutations and their effects on puberty. Horm Res, 57 Suppl 2, 35-8.

Hutt, K. J. \& Albertini, F. (2007). An oocentric view of folliculogenesis and embryogenesis. Reproductive Biomedicine 14, 758-764.

Jiang, M., Aittomaki, K., Nilsson, C., Pakarinen, P., Iitia, A., Torresani, T., Simonsen, H., Goh, V., Pettersson, K., de la Chapelle, A. \& Huhtaniemi, I. (1998). The frequency of an inactivating point mutation $(566 \mathrm{C}-->\mathrm{T})$ of the human follicle-stimulating hormone receptor gene in four populations using allele-specific hybridization and time-resolved fluorometry. J Clin Endocrinol Metab, 83, 4338-43.

Kaiser, U.B. (2003). The pathogenesis of the ovarian hyperstimulation syndrome. $N$ Engl J Med, 349, 729-32. 
Kopp, P., van Sande, J., Parma, J., Duprez, L., Gerber, H., Joss, E., Jameson, J.L., Dumont, J.E. \& Vassart, G. (1995). Brief report: congenital hyperthyroidism caused by a mutation in the thyrotropin-receptor gene. $N$ Engl J Med, 332, 150-4.

Krishnamurthy, J., Kannan, K., Feng, J., Mohanprasad, B.K., Tsuchida, N. \& Shanmugam, G. (2001). Mutational analysis of the candidate tumor suppressor gene ING1 in Indian oral squamous cell carcinoma. Oral Oncol, 37, 222-4.

Kumar, T.R. (2005). What have we learned about gonadotropin function from gonadotropin subunit and receptor knockout mice? Reproduction, 130, 293-302.

Kumar, T.R., Low, M.J. \& Matzuk, M.M. (1998). Genetic rescue of follicle-stimulating hormone beta-deficient mice. Endocrinology, 139, 3289-95.

Kumar, T.R., Wang, Y., Lu, N. \& Matzuk, M.M. (1997). Follicle stimulating hormone is required for ovarian follicle maturation but not male fertility. Nat Genet, 15, 201-4.

Lass, A., Silye, R., Abrams, D.C., Krausz, T., Hovatta, O., Margara, R. \& Winston, R.M. (1997). Follicular density in ovarian biopsy of infertile women: a novel method to assess ovarian reserve. Hum Reprod, 12, 1028-31.

Latronico, A.C., Anasti, J., Arnhold, I.J., Rapaport, R., Mendonca, B.B., Bloise, W., Castro, M., Tsigos, C. \& Chrousos, G.P. (1996). Brief report: testicular and ovarian resistance to luteinizing hormone caused by inactivating mutations of the luteinizing hormonereceptor gene. $N$ Engl J Med, 334, 507-12.

Layman, L.C., Porto, A.L., Xie, J., da Motta, L.A., da Motta, L.D., Weiser, W. \& Sluss, P.M. (2002). FSH beta gene mutations in a female with partial breast development and a male sibling with normal puberty and azoospermia. J Clin Endocrinol Metab, 87, 3702-7.

Lindstedt, G., Nystrom, E., Matthews, C., Ernest, I., Janson, P.O. \& Chatterjee, K. (1998). Follitropin (FSH) deficiency in an infertile male due to FSHbeta gene mutation. A syndrome of normal puberty and virilization but underdeveloped testicles with azoospermia, low FSH but high lutropin and normal serum testosterone concentrations. Clin Chem Lab Med, 36, 663-5.

Lipitz, S., Grisaru, D., Achiron, R., Ben-Baruch, G., Schiff, E. \& Mashiach, S. (1996). Spontaneous ovarian hyperstimulation mimicking an ovarian tumour. Hum Reprod, 11, 720-1.

Ludwig, M., Gembruch, U., Bauer, O. \& Diedrich, K. (1998). Ovarian hyperstimulation syndrome (OHSS) in a spontaneous pregnancy with fetal and placental triploidy: information about the general pathophysiology of OHSS. Hum Reprod, 13, 2082-7.

Magoffin, D.A. (2005). Ovarian theca cell. Int J Biochem Cell Biol, 37, 1344-9.

Meduri, G., Charnaux, N., Driancourt, M.A., Combettes, L., Granet, P., Vannier, B., Loosfelt, H. \& Milgrom, E. (2002). Follicle-stimulating hormone receptors in oocytes? J Clin Endocrinol Metab, 87, 2266-76.

Meduri, G., Touraine, P., Beau, I., Lahuna, O., Desroches, A., Vacher-Lavenu, M.C., Kuttenn, F. \& Misrahi, M. (2003). Delayed puberty and primary amenorrhea associated with a novel mutation of the human follicle-stimulating hormone receptor: clinical, histological, and molecular studies. J Clin Endocrinol Metab, 88, 3491-8.

Meng, E.C. \& Bourne, H.R. (2001). Receptor activation: what does the rhodopsin structure tell us? Trends Pharmacol Sci, 22, 587-93.

Minegishi, T., Nakamura, K., Takakura, Y., Ibuki, Y., Igarashi, M. \& Minegish, T. (1991). Cloning and sequencing of human FSH receptor cDNA. Biochem Biophys Res Commun, 175, 1125-30.

Misrahi, M., Meduri, G., Pissard, S., Bouvattier, C., Beau, I., Loosfelt, H., Jolivet, A., Rappaport, R., Milgrom, E. \& Bougneres, P. (1997). Comparison of immunocytochemical and molecular features with the phenotype in a case of 
incomplete male pseudohermaphroditism associated with a mutation of the luteinizing hormone receptor. J Clin Endocrinol Metab, 82, 2159-65.

Miyano, T., \& Manabe, N., (2007) Oocyte growth and acquisition of meiotic competence Soc Reprod Fertiol Suppl. 63, 531-8

Montanelli, L., Delbaere, A., Di Carlo, C., Nappi, C., Smits, G., Vassart, G. \& Costagliola, S. (2004). A mutation in the follicle-stimulating hormone receptor as a cause of familial spontaneous ovarian hyperstimulation syndrome. J Clin Endocrinol Metab, 89, 1255 8.

Montgomery, G.W., Duffy, D.L., Hall, J., Kudo, M., Martin, N.G. \& Hsueh, A.J. (2001). Mutations in the follicle-stimulating hormone receptor and familial dizygotic twinning. Lancet, 357, 773-4.

Moyle, W.R., Campbell, R.K., Myers, R.V., Bernard, M.P., Han, Y. \& Wang, X. (1994). Coevolution of ligand-receptor pairs. Nature, 368, 251-5.

Nappi, R.G., Di Naro, E., D'Aries, A.P. \& Nappi, L. (1998). Natural pregnancy in hypothyroid woman complicated by spontaneous ovarian hyperstimulation syndrome. Am J Obstet Gynecol, 178, 610-1.

O'Shaughnessy, P.J., Bennett, M.K., Scott, I.S. \& Charlton, H.M. (1992). Effects of FSH on Leydig cell morphology and function in the hypogonadal mouse. $J$ Endocrinol, 135, 517-25.

Palczewski, K., Kumasaka, T., Hori, T., Behnke, C.A., Motoshima, H., Fox, B.A., Le Trong, I., Teller, D.C., Okada, T., Stenkamp, R.E., Yamamoto, M. \& Miyano, M. (2000). Crystal structure of rhodopsin: A G protein-coupled receptor. Science, 289, 739-45.

Perez Mayorga, M., Gromoll, J., Behre, H.M., Gassner, C., Nieschlag, E. \& Simoni, M. (2000). Ovarian response to follicle-stimulating hormone (FSH) stimulation depends on the FSH receptor genotype. $J$ Clin Endocrinol Metab, 85, 3365-9.

Phillip, M., Arbelle, J.E., Segev, Y. \& Parvari, R. (1998). Male hypogonadism due to a mutation in the gene for the beta-subunit of follicle-stimulating hormone. $N$ Engl $J$ Med, 338, 1729-32.

Poirot, C., Vacher-Lavenu, M.C., Helardot, P., Guibert, J., Brugieres, L. \& Jouannet, P. (2002). Human ovarian tissue cryopreservation: indications and feasibility. Hum Reprod, 17, 1447-52.

Quellari, M., Desroches, A., Beau, I., Beaudeux, E. \& Misrahi, M. (2003). Role of cleavage and shedding in human thyrotropin receptor function and trafficking. Eur $J$ Biochem, 270, 3486-97.

Rannikko, A., Pakarinen, P., Manna, P.R., Beau, I., Misrahi, M., Aittomaki, K. \& Huhtaniemi, I. (2002). Functional characterization of the human FSH receptor with an inactivating Ala189Val mutation. Mol Hum Reprod, 8, 311-7.

Rodien, P., Bremont, C., Sanson, M.L., Parma, J., Van Sande, J., Costagliola, S., Luton, J.P., Vassart, G. \& Duprez, L. (1998). Familial gestational hyperthyroidism caused by a mutant thyrotropin receptor hypersensitive to human chorionic gonadotropin. $N$ Engl $J$ Med, 339, 1823-6.

Schnorr, J.A., Jr., Miller, H., Davis, J.R., Hatch, K. \& Seeds, J. (1996). Hyperreactio luteinalis associated with pregnancy: a case report and review of the literature. Am J Perinatol, 13, 95-7.

Smits, G., Campillo, M., Govaerts, C., Janssens, V., Richter, C., Vassart, G., Pardo, L. \& Costagliola, S. (2003). Glycoprotein hormone receptors: determinants in leucine-rich repeats responsible for ligand specificity. Embo J, 22, 2692-703.

Sudo, S., Kudo, M., Wada, S., Sato, O., Hsueh, A.J. \& Fujimoto, S. (2002). Genetic and functional analyses of polymorphisms in the human FSH receptor gene. Mol Hum Reprod, 8, 893-9. 
Sundblad, V., Chiauzzi, V.A., Escobar, M.E., Dain, L. \& Charreau, E.H. (2004). Screening of FSH receptor gene in Argentine women with premature ovarian failure (POF). Mol Cell Endocrinol, 222, 53-9.

Themmen, A.P. (2005). An update of the pathophysiology of human gonadotrophin subunit and receptor gene mutations and polymorphisms. Reproduction, 130, 263-74.

Themmen, A.P.N. \& Huhtaniemi, I.T. (2000). Mutations of gonadotropins and gonadotropin receptors: elucidating the physiology and pathophysiology of pituitary-gonadal function. Endocr Rev, 21, 551-83.

Touraine, P., Beau, I., Gougeon, A., Meduri, G., Desroches, A., Pichard, C., Detoeuf, M., Paniel, B., Prieur, M., Zorn, J.R., Milgrom, E., Kuttenn, F. \& Misrahi, M. (1999). New natural inactivating mutations of the follicle-stimulating hormone receptor: correlations between receptor function and phenotype. Mol Endocrinol, 13, 1844-54.

Urizar, E., Montanelli, L., Loy, T., Bonomi, M., Swillens, S., Gales, C., Bouvier, M., Smits, G., Vassart, G. \& Costagliola, S. (2005). Glycoprotein hormone receptors: link between receptor homodimerization and negative cooperativity. Embo J, 24, 1954-64.

Vaskivuo, T.E., Aittomaki, K., Anttonen, M., Ruokonen, A., Herva, R., Osawa, Y., Heikinheimo, M., Huhtaniemi, I. \& Tapanainen, J.S. (2002). Effects of folliclestimulating hormone (FSH) and human chorionic gonadotropin in individuals with an inactivating mutation of the FSH receptor. Fertil Steril, 78, 108-13.

Vassart, G. (2004). Activating mutations of the TSH receptor. Thyroid, 14, 86-7.

Vassart, G., Pardo, L. \& Costagliola, S. (2004). A molecular dissection of the glycoprotein hormone receptors. Trends Biochem Sci, 29, 119-26.

Vasseur, C., Rodien, P., Beau, I., Desroches, A., Gerard, C., de Poncheville, L., Chaplot, S., Savagner, F., Croue, A., Mathieu, E., Lahlou, N., Descamps, P. \& Misrahi, M. (2003). A chorionic gonadotropin-sensitive mutation in the follicle-stimulating hormone receptor as a cause of familial gestational spontaneous ovarian hyperstimulation syndrome. $N$ Engl J Med, 349, 753-9.

Vihko, K.K., LaPolt, P.S., Nishimori, K. \& Hsueh, A.J. (1991). Stimulatory effects of recombinant follicle-stimulating hormone on Leydig cell function and spermatogenesis in immature hypophysectomized rats. Endocrinology, 129, 1926-32.

Vlaeminck-Guillem, V., Ho, S.C., Rodien, P., Vassart, G. \& Costagliola, S. (2002). Activation of the cAMP pathway by the TSH receptor involves switching of the ectodomain from a tethered inverse agonist to an agonist. Mol Endocrinol, 16, 736-46

Yamamoto, K., Otoi, T., Koyama, N., Horikita, N., Tachikawa, S., \& Miyano, T., Development to live young from bovine small oocytes after growth, maturation and fertilization in vitro. Theriogenology 52, 81-9

Zalel, Y., Orvieto, R., Ben-Rafael, Z., Homburg, R., Fisher, O. \& Insler, V. (1995). Recurrent spontaneous ovarian hyperstimulation syndrome associated with polycystic ovary syndrome. Gynecol Endocrinol, 9, 313-5.

Zeleznik, A.J. (2004). The physiology of follicle selection. Reprod Biol Endocrinol, 2, 31.

Zhang, M., Tong, K.P., Fremont, V., Chen, J., Narayan, P., Puett, D., Weintraub, B.D. \& Szkudlinski, M.W. (2000). The extracellular domain suppresses constitutive activity of the transmembrane domain of the human TSH receptor: implications for hormonereceptor interaction and antagonist design. Endocrinology, 141, 3514-7. 


\section{Figure Legends}

\section{Figure 1}

\section{Histological studies in the ovaries of patients with FSHR mutations.}

I; Totally inactivating mutation (Paris 1). II and III: partially inactivating mutations Paris 2 and Paris 3 respectively (see text).

A, E, I: Low magnification of the ovarian cortex showing the reserve follicles (arrows) Note the elevated follicular concentration in A.

I -B: Normal primary follicle C: Primary follicle labeled with the proliferation marker PCNA. D: c-Kit expression in the oocyte of an intermediary follicle.

II-F: Normal secondary follicle with a multilayered granulosa and a developing theca interna. G: abnormal antral follicle with a hypertrophic theca interna and an absent granulosa. $\mathrm{H}$ : Labeling of the hypertrophic theca interna of an antral follicle with the anti P450c17a antibody. Note the degenerating granulosa cells and the irregularly shaped antrum.

III-J: Normal secondary follicle with a multilayered granulosa and a well developed intact basal lamina. K: abnormal antral follicle with a hypertrophic theca interna and an almost totally absent granulosa. L: Labeling of the hypertrophic theca interna of an antral follicle with the anti P450c17 $\alpha$ antibody; GC: granulosa cells; TI: Theca interna; bl: basal lamina; a: antrum.

\section{Figure 2}

\section{Loss of function FSHR mutations of the FSHR}

A: Ultrasonography of patient Paris 3 showing several antral follicles up to $5 \mathrm{~mm}$ diameter.

B: Localisation of natural loss-of function mutations of the FSH receptor. See text for references.

C: Comparative functional studies of loss-of function mutations of the FSHR. The maximal stage of follicular maturation is illustrated below. 


\section{Figure 3}

Familial spontaneous OHSS (Vasseur et al, 2003).

A: Ultrasonographyc study of the enlarged proband's ovary during pregnancy showing multiple cysts.

B: Histological study of an ovarian biopsy from an affected sister. Large cyst (CY) lined by several layers of luteinized granulosa (LG) and theca cells (TC).

Inset: Strong magnification of the luteinized cells with an abundant eosinophilic vacuolated cytoplasm.

C: Pedigree of the family: Pregnancies with reported symptoms of OHSS are indicated (+). The genotype is indicated when available.

Figure 4

Hormonal values of the proband with spontaneous OHSS during pregnancy.

Figure 5

Mutations of the FSHR found in spontaneous OHSS

References are: T449I:Vasseur et al, 2003. D567N: Smits et al, 2003. ; T449A: Montanelli et al, 2004, D567G Costagliola S et al, 2005. I545T: De Leener et al, 2005 ; 
Table 1 : Natural FSHR mutations:

\begin{tabular}{|c|c|c|c|c|c|}
\hline $\begin{array}{l}\text { PATIENT/ } \\
\text { FSHR } \\
\text { Mutation }\end{array}$ & Puberty & Amenorrhea & Ovary & $\begin{array}{l}\text { Ovarian } \\
\text { Histology }\end{array}$ & $\begin{array}{l}\text { Receptor } \\
\text { function } \\
\text { in vitro }\end{array}$ \\
\hline $\begin{array}{l}\text { Paris 1* } \\
\text { Pro519Thr }\end{array}$ & Delayed & primary & hypoplasic & $\begin{array}{l}\uparrow p r i m o r d i a l \\
\text { and primary } \\
\text { follicles }\end{array}$ & $\begin{array}{l}\text { Total loss of } \\
\text { function }\end{array}$ \\
\hline $\begin{array}{l}\text { Finnish1** } \\
\text { Ala189Val }\end{array}$ & delayed & primary & hypoplasic & $\begin{array}{l}\downarrow \text { primordial } \\
\downarrow \text { Secondary } \\
\text { rare mature } \\
\text { follicles }\end{array}$ & $\begin{array}{l}\text { c-AMP: } \\
\text { 2 29\% of WT } \\
\text { FSHR } \\
\text { IP3: almost } \\
\text { totally lost }\end{array}$ \\
\hline $\begin{array}{l}\text { Paris 2*** } \\
\text { Asp224Val } \\
\text { Leu601Val }\end{array}$ & normal & primary & normal & $\begin{array}{l}\text { Primordial } \\
\text { primary } \\
\text { secondary } \\
\text { and antral } \\
\text { follicles up to } \\
3 \mathrm{~mm} \\
\text { diameter }\end{array}$ & $\begin{array}{l}\text { c-AMP: } \\
\sim 4 \% \text { and } \\
12 \% \text { of WT } \\
\text { FSHR }\end{array}$ \\
\hline $\begin{array}{l}\text { Paris } 3^{* * * *} \\
\text { lle160Thr } \\
\text { Arg573Cys }\end{array}$ & normal & secondary & normal & $\begin{array}{l}\text { Primordial } \\
\text { primary } \\
\text { secondary } \\
\text { and antral } \\
\text { follicles up to } \\
5 \mathrm{~mm} \\
\text { diameter }\end{array}$ & $\begin{array}{l}\text { C-AMP: } \\
\sim 9 \% \text { and } \\
24 \% \text { of WT } \\
\text { FSHR }\end{array}$ \\
\hline
\end{tabular}

\section{Animal Model}

\begin{tabular}{|l|l|l|l|l|l|}
\hline $\begin{array}{l}\text { FSHR KO } \\
\text { Mice\# }\end{array}$ & & hypoplasic & $\begin{array}{l}\text { Primordial, } \\
\text { primary, } \\
\text { secondary } \\
\text { follicles }\end{array}$ & $\begin{array}{l}\text { Total } \\
\text { inactivation }\end{array}$ \\
\hline
\end{tabular}

Table 1: References :*Meduri G et al.2003; ${ }^{* \star}$ Aittomaki K et al, 1996 ; Rannikko A et al, 2002.

${ }^{* \star *}$ Touraine P et al 1998 ; ${ }^{* * \star * B e a u ~ I ~ e t ~ a l .1998 . ~ ; ~ \# D i e r i c h ~ a ~ e t ~ a l .1998 . ~ ; W T ~ F S H R: ~ W i l d-t y p e ~ F S H ~}$ receptor. 


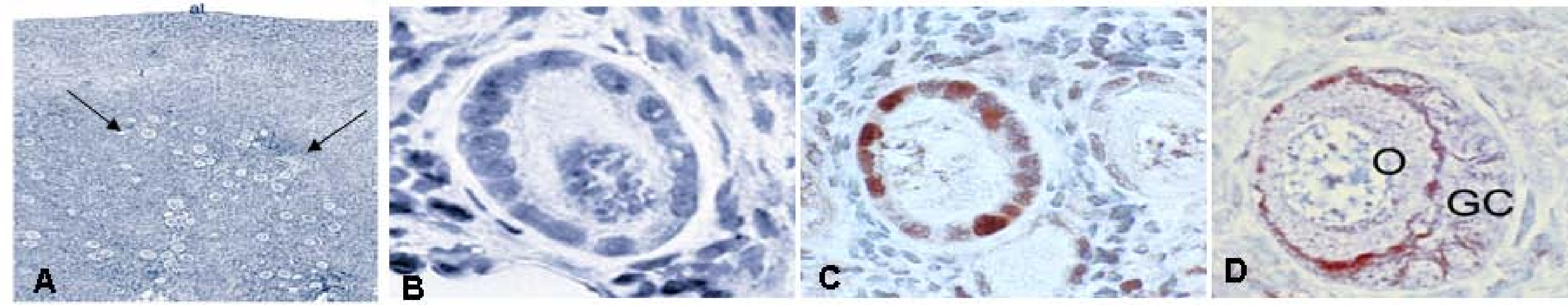

II
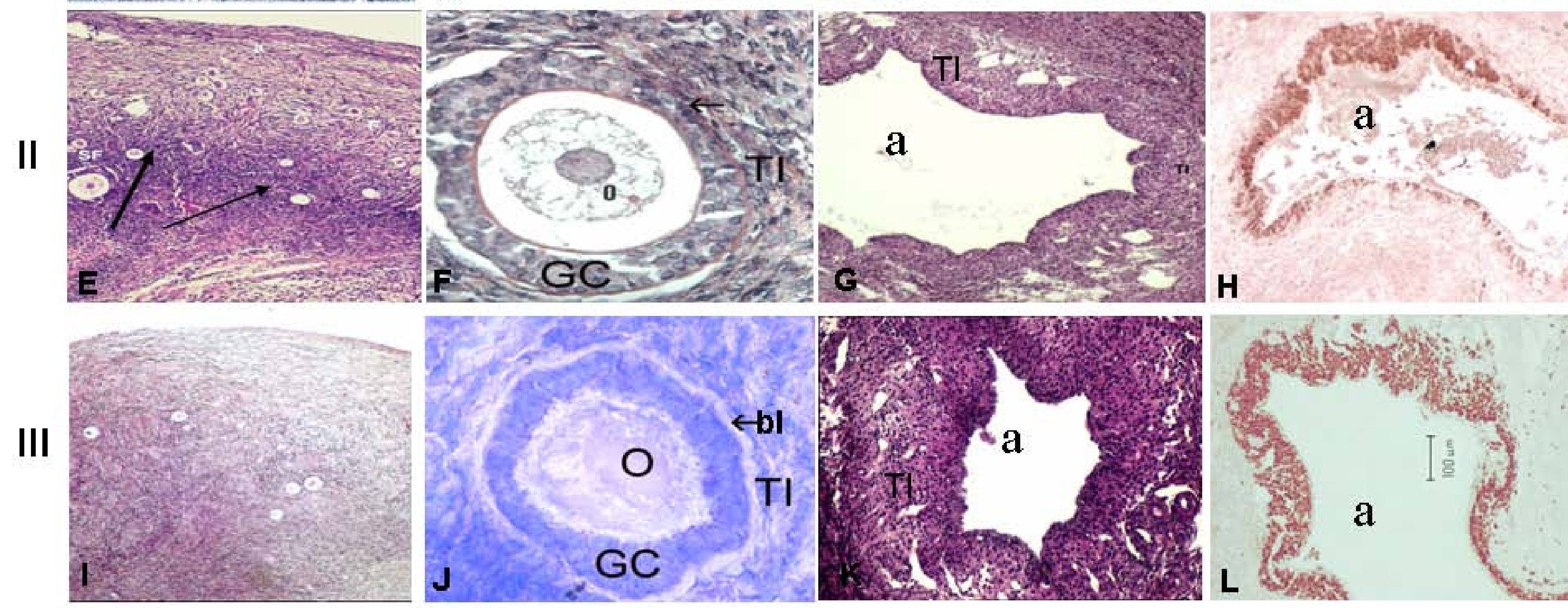

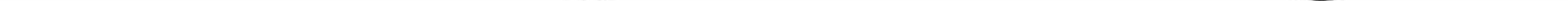


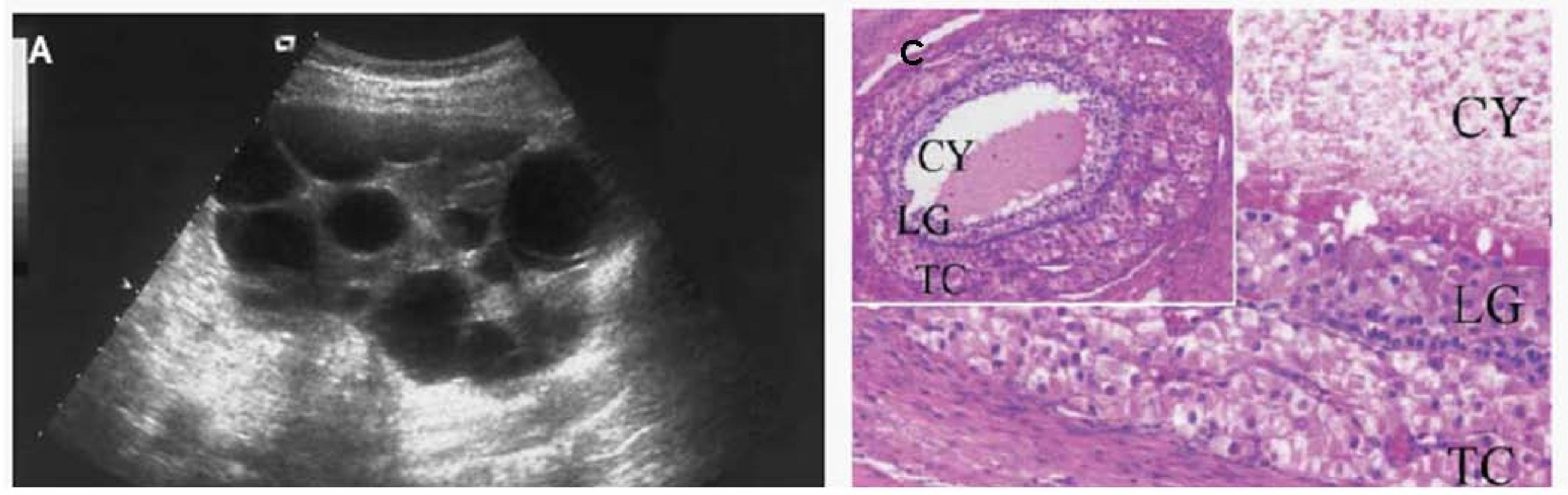
B

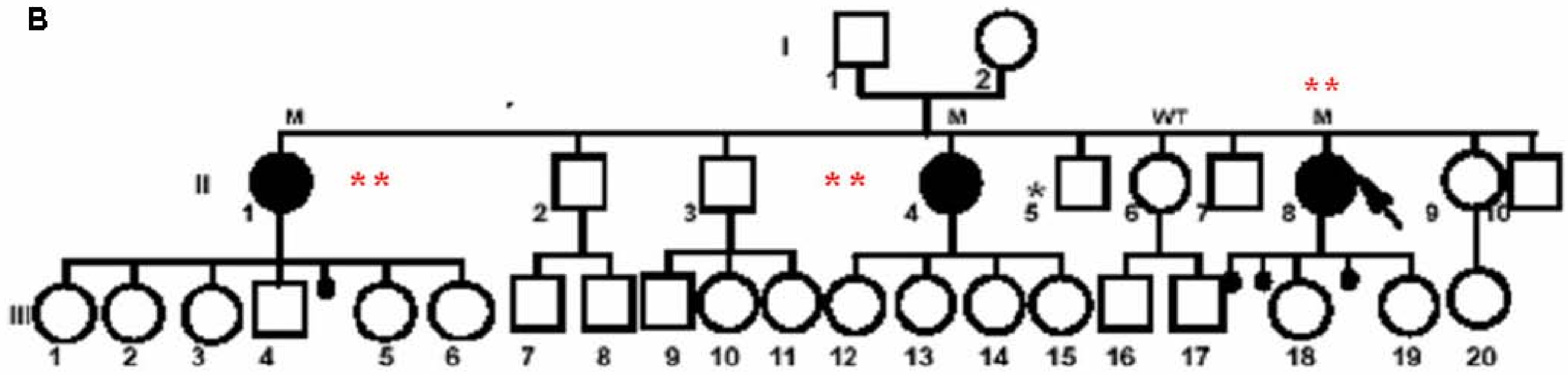
t
OHSS:
$-\quad-++++$
FSHR: $\quad *$ T449I
$-\quad++/--/+-+++1-$
**T449I *T449
**T449I 


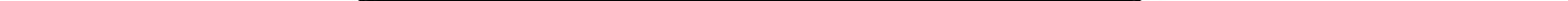




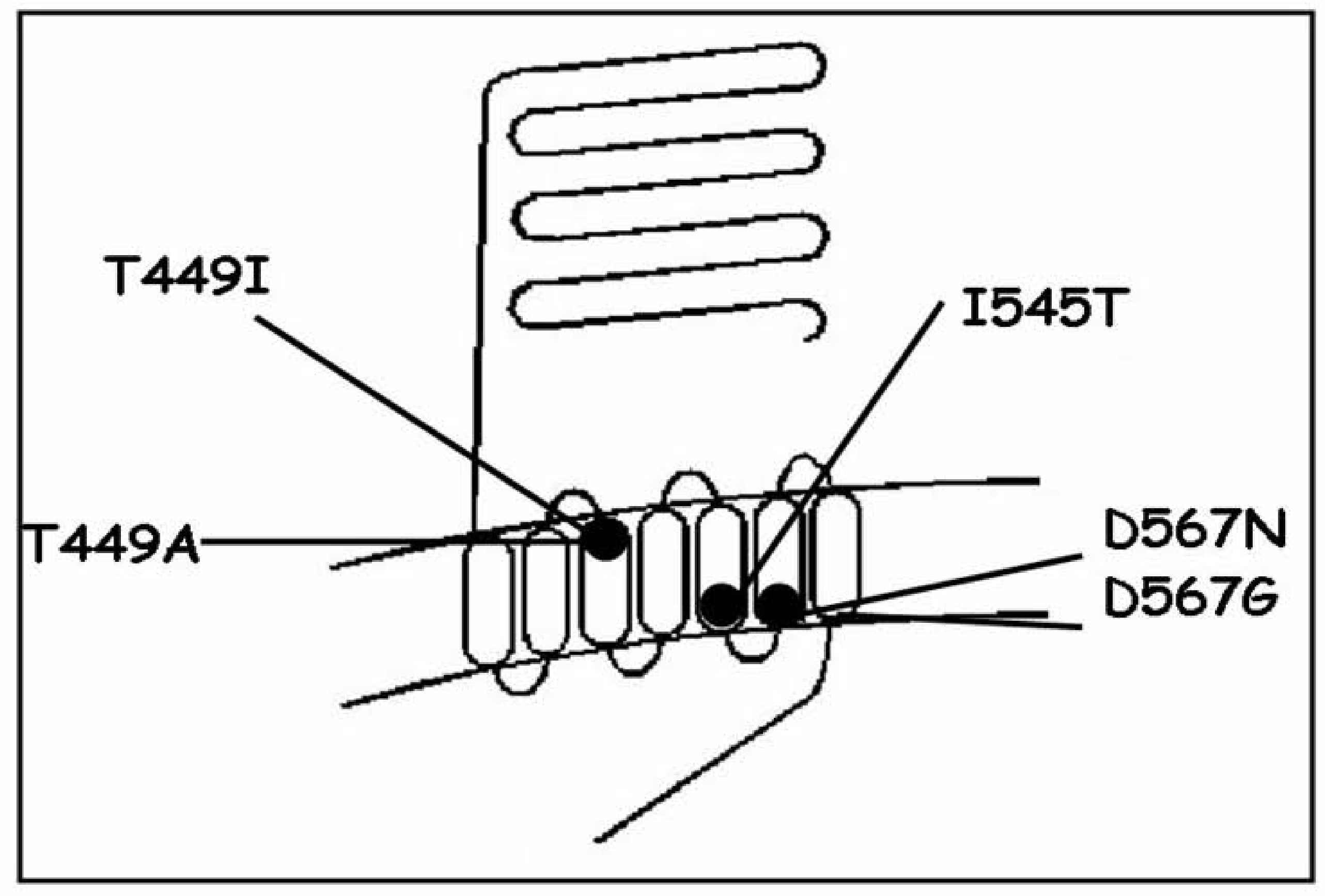

Fig.5 